\title{
ASSESSMENT OF THE ENVIRONMENTAL COMPONENT OF SUNFLOWER PRODUCTION IN AGRICULTURAL ENTERPRISES
}

\author{
Kateryna Honcharova', Kseniia Kirichenko²
}

\begin{abstract}
Introduction. The article highlights the fact that over the past twenty years, sunflower production in Ukraine has increased significantly as a result of the expansion of cultivated areas and an increase in yields. In 2019, the gross harvest of sunflower exceeded 15 million tons, which was an all-time record. At the same time, the authors draw attention to the fact that the rapid spread of sunflowers in the structure of cultivated areas creates significant problems related to the maintenance of soil fertility. The purpose of this article is to assess the level of environmental factor of sunflower production in agricultural enterprises of Kharkiv region. Results. The paper proposes its own methodical approach to assess the environmental factor of production. This approach takes into account the level of actual application of mineral fertilizers according to their various components, as well as organic fertilizers, summarized by the coefficients of mineral and organic fertilizer application rates. Given the level of variability, they form a total fertilizer application rate. It is also proposed to consider the compliance of the actual share of sunflower in the structure of cultivated areas with the normative value through the calculation of the coefficient of the normative area of sunflower. Ultimately, all indicators of the level of environmental factor of sunflower production are combined into one, called the coefficient of environmental friendliness of sunflower production. Approbation of this methodical approach on the example of agricultural enterprises of Kharkiv region according to the data of 2019 allowed the authors to establish the fact that the value of the factor of the environmental factor of sunflower production in the vast majority of enterprises was at 0.11-0.2 (181 enterprises) and 0.21-0.3 146 enterprises). The article notes that compliance with regulatory requirements for planted acreage was slightly better than regulatory requirements for fertilizer application. The authors found a correlation between the coefficient of the environmental factor of sunflower production and the share of the cultivated areas occupied by sunflowers in their total value. Conclusions. Studying the environmental factor of sunflower production, the authors proposed a methodical approach to determine the eco-factor of sunflower production. It allows an objective assessment of the problems associated with compliance with existing requirements for the recovery of nutrients in the soil and crop areas.
\end{abstract}

Key words: sunflower, level of soil fertility, structure of sown areas, restoration of nutrients, ecological coefficient of sunflower production.

JEL Classification: Q51, Q18

\section{Introduction}

In recent years, agriculture has shown good economic growth. In 2019, the gross harvest of grains and legumes reached 75 million tons, more than 15 million of which are sunflowers. This is significantly higher than in 1990. Expectations for the current year of 2021 are also positive. According to forecasts, the gross harvest of grain will exceed the level of 2019 .

Corresponding author:

${ }^{1}$ Simon Kuznets Kharkiv National University of Economics, Ukraine

E-mail: ekateryna.honcharova@i.ua

ORCID: https://orcid.org/0000-0002-0495-3031

${ }^{2}$ Simon Kuznets Kharkiv National University of Economics, Ukraine ORCID: https://orcid.org/0000-0002-8366-7577
There is also a significant increase in crop yields. Over the past twenty years, the yield of grain and legume crops has increased by 2.2 times and sunflower by 1.7 times.

However, there are both current and systemic problems in agriculture. One of the most important among them is to maintain the level of soil fertility. This component has many aspects related to the structure of production 
and compliance with norms on the amount of organic fertilizers.

A significant number of researchers note the uncontrolled growth of the sunflower share in the structure of sown areas of agricultural crops among the issues in need of state regulation. In 2020 , the sown area of sunflower in agricultural enterprises was 5.25 million hectares or $25.6 \%$ of the total area. At the same time, in accordance with scientifically substantiated requirements, this figure should not exceed $10-12 \%$. Moreover, in the Polesia zone it is not recommended to have sunflowers in the structure of cultivated areas at all.

One of the reasons for this phenomenon is that companies have to pay significant rents for land leased from peasants. This is due to the high level of competition for the right to own and dispose of leased land. In addition, today in Ukraine, rental payments constitute a noticeable share of the income of the rural population. On this basis, it can be argued that the level of payments for the lease of shares acts as an important social component of rural area development policy. Thus, the success of financial and economic activities of agricultural enterprises today largely determines the level of income of a large number of households in rural areas, and not just the heads of these enterprises. Due to its high profitability, sunflower production is one of the main factors in the formation of an appropriate level of competitiveness of each enterprise.

The analysis of the economic and environmental results of sunflower production is of great interest among scientists. The works of Kondratyuk N. (Kondratyuk, 2013, 2004), Kontseby S. (Kontseby, 2014), Perebyinis V. (Perebyinis, 2014), Runcheva N., Britvenko A. (Runcheva, Britvenko, 2012, 2019), Pisarenko S., Mykolenko I. (Pisarenko, Mykolenko, 2010) et.al., are devoted to this problem. These works raise various issues related to the efficiency of sunflower production, its trends, marketing, and other aspects. However, the problem of efficiency in terms of the ecological component is almost not covered.

The aim of the article is to assess the level of environmental factor of sunflower production in agricultural enterprises of Kharkiv region.

\section{Methodological principles for assessing the ecological production of sunflower}

The object of the study were agricultural enterprises in Kharkiv region, which had sunflower areas in the structure of land use according to the results of activity in 2019. There were 503 such enterprises. This is a sufficient number to obtain reliable results in the construction of groupings and dependencies.

First, consider the methodological principles underlying the determination of the level of environmental friendliness of sunflower production in agricultural enterprises. The first provision concerns the level of nutrient extraction in sunflower production. According to the recommendations of National Scientific Center "Institute for Soil Science and Agrochemistry Research named after O. N. Sokolovsky", the system of fertilizers in a short rotatory field crop rotation on chernozems and gray forest soils in the subzone of unstable moisture Forest-Steppe with a saturation of $80 \%$ grain and $20 \%$ sunflower allows for $50 \mathrm{t} / \mathrm{ha}$ of organic fertilizers and mineral fertilizers to N90P60K90 (Zaryshniak, 2008). Therefore, this situation is optimal for restoring soil fertility levels. If companies do not adhere to the recommended amount of fertilizers, they violate the technology of soil fertility restoration.

To establish the level of soil fertility restoration through fertilizer application, it is proposed to determine the coefficient of mineral fertilizer application rate by the following formula:

$$
K_{r r m f}=\frac{\sum \beta \times F_{n p k}}{\sum \beta \times N_{n p k}}
$$

where:

$K_{r r m f}$ - regulation of the rate of mineral fertilization;

$F_{n p k}$ - the actual amount of mineral fertilizer applied;

$N_{n p k}$ - normative amount of mineral fertilizer application $\mathrm{N}_{90} \mathrm{P}_{60} \mathrm{~K}_{90}$;

$\beta$ - the share of the i-th type of mineral fertilizers in the total amount.

In this case, with the mineral fertilizer structure NPK 90:60:90, the proportion of each type of fertilizer will be $0.375: 0.25: 0.375$ or $37.5 \%, 25.0 \%$ and $37.5 \%$ respectively.

Similarly, the coefficient of organic fertilizer application rate is determined:

$$
K_{\text {rrof }}=\frac{F_{\text {org }}}{N_{\text {org }}}
$$

where:

$K_{\text {rrof }}$ - regulation of the rate of application of organic fertilizers; 
$F_{\text {org }}$ - the actual amount of organic fertilizer applied;

$N_{\text {org }}$ - normative amount of applied organic fertilizers (50 t/ha).

The next step is to determine the total application rate factor using the formula:

$$
K_{r r f}=\beta_{i} K_{r r m f}+\beta_{i} K_{r r o f}
$$

where:

$K_{r r f}$ - fertilizer rate regulation.;

$\beta_{i}$ - share of the i-th type of mineral fertilizer in the total volume of nutrient application.

It was found that, according to regulatory data, $50 \mathrm{~kg}$ of manure contains approximately $725 \mathrm{~kg}$ of active ingredient. However, manure is usually applied to the same field no more than once every five years. Based on this, it was decided to divide this value by five, which gives a mineral application value of $145 \mathrm{~kg} / \mathrm{ha}$. Thus, based on the proportion of the active substance $240 \mathrm{~kg} / \mathrm{ha}$ for mineral fertilizers and $145 \mathrm{~kg} / \mathrm{ha}$ for organic fertilizers, the value of $\beta_{i}$ was determined for mineral fertilizers -0.623 , for organic fertilizers, respectively, 0.327 .

The second component of assessing the level of the environmental factor of sunflower seed production is its share in the structure of land use. According to the Decree of the Cabinet of Ministers of Ukraine "On approval of standards for the optimal ratio of crops in crop rotations in different natural and agricultural regions" from February 11, 2010 № 164, the share of sunflower in the structure of cultivated areas of the ForestSteppe zone should not exceed 9\%, and in the Northern Steppe zone no more than 10\% (9). The Kharkiv region includes both zones. As a normative indicator, the authors decided to choose the share of sunflowers in the structure of cultivated areas at $10 \%$. It is proposed to determine the second component of the evaluation of the environmental factor of sunflower production, the coefficient of the normative sowing area of sunflower by comparing the actual data on the share of sunflower in the structure of cultivated areas with the normative:

$$
K_{n s a}=\frac{S W_{n}}{S W_{f}}
$$

where:

$K_{n s a}$ - coefficient of sunflower normative sowing area;

$S W_{n}$ - the share of sunflower in the structure of sown areas according to the norm (10\%);
$S W_{f}$ - the actual share of sunflower in the sown area structure.

The third step in this methodology is the calculation of the generalized factor of the environmental factor of sunflower production according to the following formula:

$$
K_{\text {efs }=} \beta_{\sigma} K_{r r f}+\beta_{\sigma} K_{n s a}
$$

where:

$K_{\text {efs }} \quad-$ ecological factor of sunflower production;

$\beta_{\sigma}$ - the share of the indicator in accordance with the level of its variability.

It should be noted that in the ideal case, the value of the coefficient of the environmental factor of sunflower production should be equal to or greater than 1 . This value will mean that the indicators taken into account in determining this factor are equal to the normative, or better than the normative.

The variability of the indicators should be explained separately. In this case the point is that each of them has a certain level of variability. If its variability is high, then it is possible to have averages at a higher level than the one with lower variability. This, in turn, can lead to a distortion of objective reality. This is why an adjustment of this kind is necessary.

The level of variability of the indicator or the value of $\beta_{\sigma}$ for the indicator with the minimum level is determined by the formula:

$$
\beta_{\sigma}=\frac{\sigma_{i}}{\sum \sigma_{i}}
$$

where:

$\beta_{\sigma}$ - the proportion of the indicator according to the level of its variability;

$\sigma_{i}$ - is the standard deviation of the i-index.

Thus, the proposed methodological approach to determining the level of environmental factor in sunflower production takes into account, on the one hand, the level of mineral and organic fertilizers, on the other hand, the share of sunflowers in the structure of cultivated areas.

\section{Approbation of methods for assessing the ecological production of sunflower on the example of agricultural enterprises}

Table 1 shows the values obtained by agricultural enterprises in Kharkiv region in 2019 when calculating its variability; $\sigma_{i}$ is the standard deviation of the i-th indicator. In fact, it 
Table 1

The impact of the coefficient value of the environmental factor of sunflower production on some indicators of agricultural enterprises in the Kharkiv region in 2019

\begin{tabular}{|c|c|c|c|c|c|c|c|c|}
\hline $\begin{array}{c}\text { Groups } \\
\text { according } \\
\text { to the } \\
\text { environmental } \\
\text { factor }\end{array}$ & $\begin{array}{c}\text { Number of } \\
\text { enterprises }\end{array}$ & $\begin{array}{c}\text { Ecological } \\
\text { factor } \\
\text { coefficient } \\
\text { in sunflower } \\
\text { production }\end{array}$ & $\begin{array}{c}\text { Coefficient } \\
\text { of efficiency } \\
\text { of standard } \\
\text { fertilizer } \\
\text { application }\end{array}$ & $\begin{array}{c}\text { Sunflower } \\
\text { area } \\
\text { standard } \\
\text { coefficient }\end{array}$ & $\begin{array}{c}\text { Sown area, } \\
\text { ha }\end{array}$ & $\begin{array}{c}\text { Share of } \\
\text { areas using } \\
\text { mineral } \\
\text { fertilizers, \% }\end{array}$ & $\begin{array}{c}\text { Share of } \\
\text { areas that } \\
\text { use organic } \\
\text { fertilizers, \% }\end{array}$ & $\begin{array}{c}\text { Share of } \\
\text { sunflower } \\
\text { acreage } \\
\text { in the } \\
\text { structure, \% }\end{array}$ \\
\hline to 0,1 & 36 & 0,081 & 0,015 & 0,162 & 458,8 & 61,9 & 1,8 & 58,0 \\
\hline $0,11-0,2$ & 181 & 0,158 & 0,057 & 0,280 & 892,8 & 91,8 & 3,5 & 37,6 \\
\hline $0,21-0,3$ & 146 & 0,244 & 0,155 & 0,353 & 720,5 & 93,2 & 0,3 & 31,1 \\
\hline $0,31-0,4$ & 79 & 0,344 & 0,271 & 0,435 & 480,1 & 96,6 & 6,1 & 25,2 \\
\hline $0,41-0,5$ & 33 & 0,448 & 0,373 & 0,546 & 317,8 & 98,0 & 6,4 & 24,0 \\
\hline above 0,5 & 28 & 0,739 & 0,817 & 0,750 & 520,2 & 98,1 & 5,6 & 26,0 \\
\hline In the region & 503 & 0,258 & 0,184 & 0,361 & 688,4 & 91,8 & 2,9 & 33,1 \\
\hline
\end{tabular}

Source: calculated according to statistical reports of agricultural enterprises

covers the two most important issues related to sunflower production.

The authors identified six groups according to the coefficient of the environmental factor of sunflower production with values ranging from less than 0.1 to more than 0.5 . The largest number was in the groups with a coefficient of 0.11-0.2 (181 enterprises) and 0.21-0.3 (146 enterprises). Figure 1 presents a histogram of the distribution of enterprises by this indicator. The maxima in the intervals, according to the grouping data, are traced precisely.

Thus, it can be said that in most companies, the value of the environmental factor of sunflower production does not exceed 0.3. The share of them in the total volume is $72.2 \%$.

As for the two components of the environmental factor in sunflower production, namely the coefficient of fertilizer application rate and the coefficient of sunflower planting area rate, both of

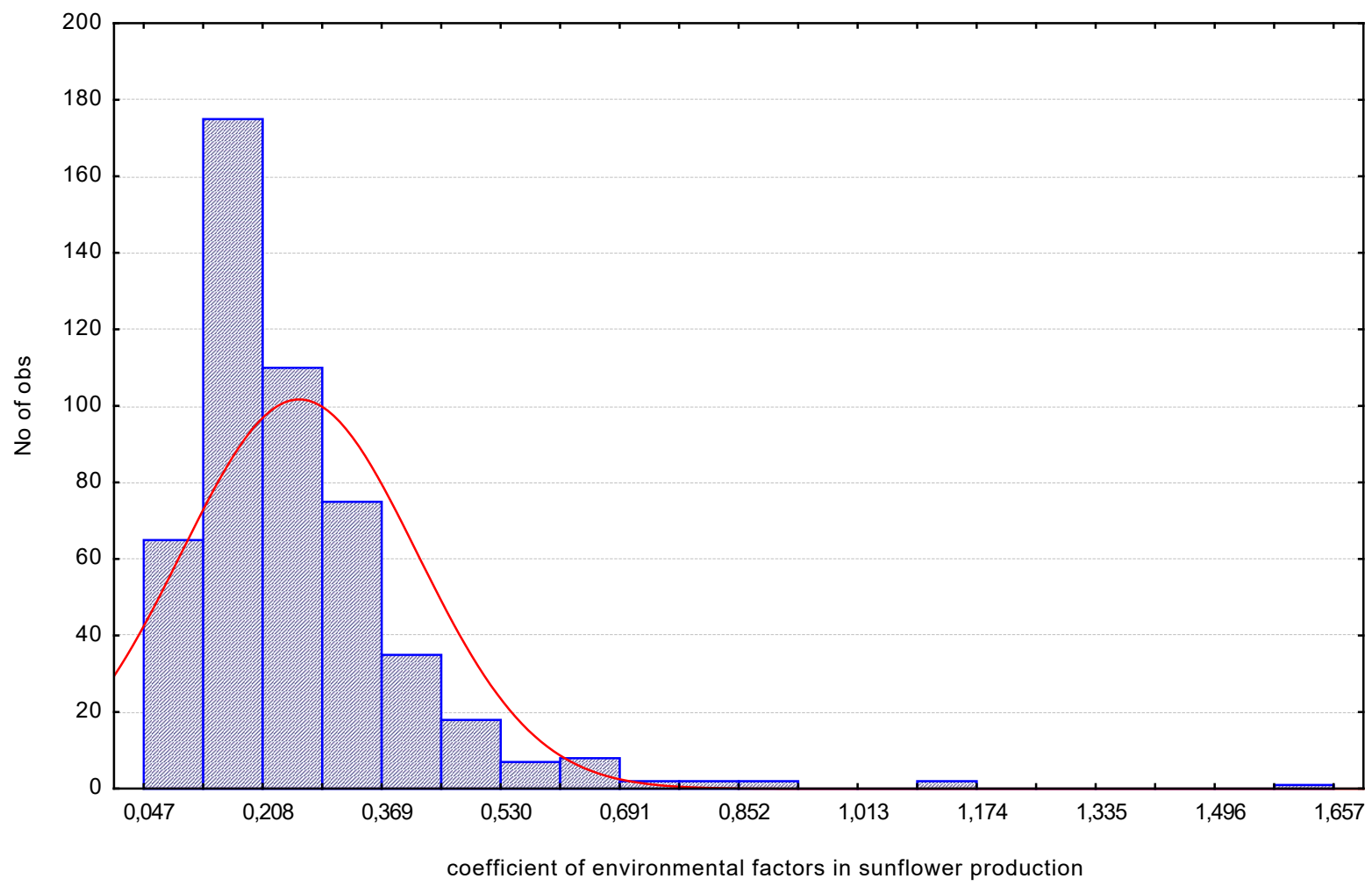

Figure 1. Histogram of the distribution of agricultural enterprises according to the value of the environmental factor of sunflower production in Kharkiv region in 2019 
them should ideally be equal to or greater than 1 . However, their average value was much lower. It was 0.184 and 0.361 , respectively.

On this basis, it can be said that the situation with respect to the normative requirements for sowing areas was somewhat better than the normative requirements for fertilizer application. However, there were some peculiarities in this case as well. In the groups with the coefficient of the environmental factor of sunflower production up to 0.5 , the coefficient of sunflower planting area was higher than the coefficient of fertilizer application.

The situation was different in the groups with the value of the coefficient of the environmental factor of sunflower production more than 0.5. The table also presents the indicators of the share of cultivated areas on which mineral and organic fertilizers were applied to the total sown area. As for mineral fertilizers, on average in the region they were used on $91.8 \%$ of the area. The lowest value of this indicator was $61.9 \%$ at the enterprises with the value of the ecological coefficient of 0.1 , and the highest was $98.1 \%$ at the enterprises of the last group. The share of the area where organic fertilizers were used turned out to be very insignificant. On average in the region organic fertilizers were applied to an area of only $2.9 \%$ of its total value. In fact, this means that organic fertilizers are in short supply today and are practically not used in the process of restoring soil fertility.

The authors also studied the relationship between the environmental factor of sunflower production and the share of sunflowers in the structure of the sown areas of all crops. It can be argued that the results obtained indicate an inverse correlation between these indicators. This is quite logical and closely related to the methodology of determining the coefficient of the environmental factor of sunflower production. In the group with a value of up to 0.1 , the share of sunflower was $58.0 \%$, in the group with a coefficient of $0.21-0.3$ it was $31.1 \%$, and in the group with a coefficient over 0.5 it was $26 \%$. On average, the value of this indicator at the enterprises of the region was at the level of $33.1 \%$, which significantly exceeds the normative value.

This trend is confirmed by the results of the relationship between the coefficient of the environmental factor of sunflower production and the share of cultivated areas occupied by

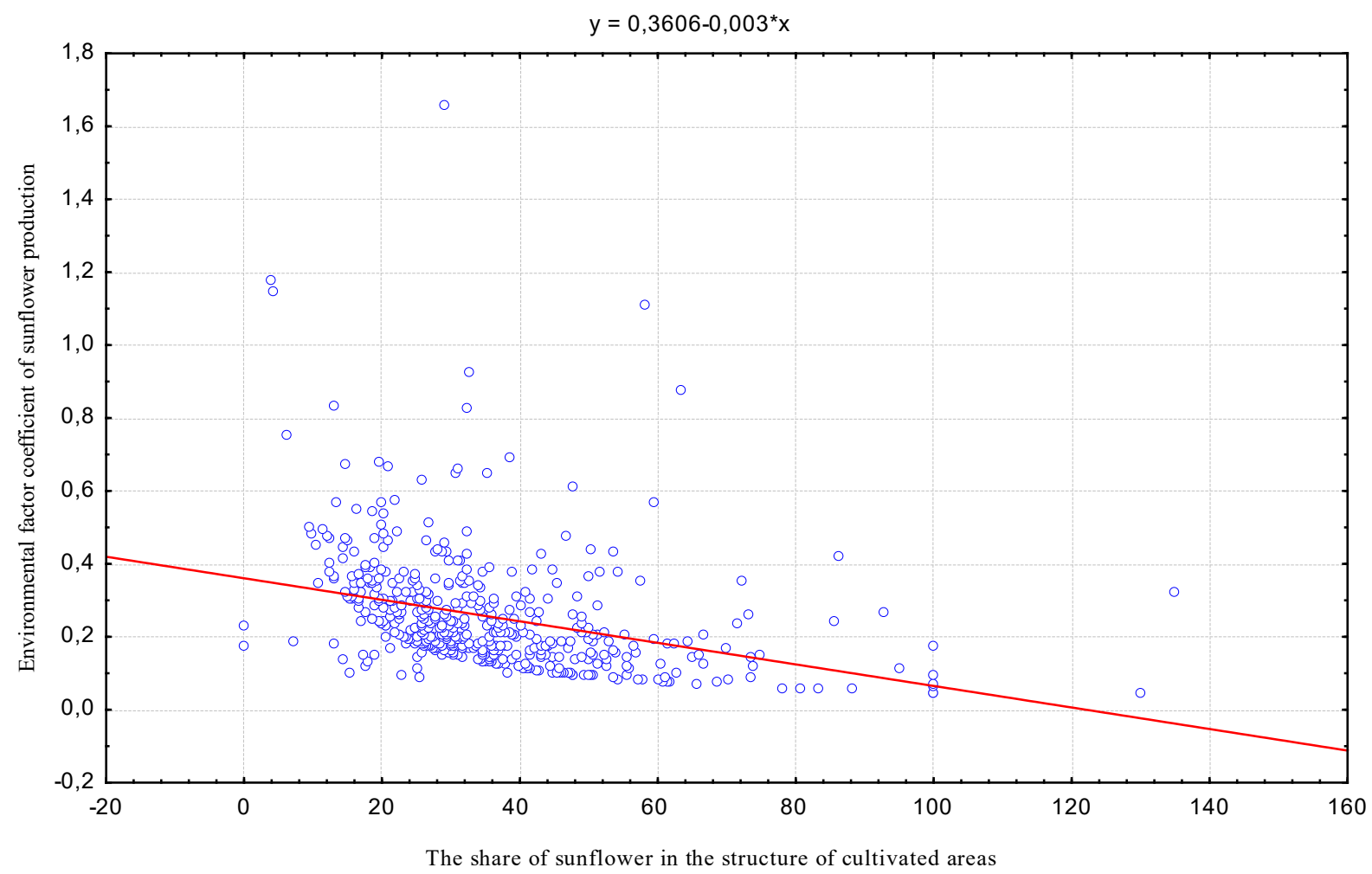

Figure 2. Dependence of the coefficient of the environmental factor of sunflower production on the share of cultivated areas occupied by sunflowers in agricultural enterprises of Kharkiv region in 2019 
sunflowers in their total value for all surveyed enterprises (Figure 2). The resulting regression equation shows that each $1 \%$ increase in the share of cultivated areas occupied by sunflowers leads to a 0.003 decrease in the value of the ecological coefficient of sunflower production.

\section{Conclusions}

The study of the environmental factor of sunflower production in agricultural enterprises of Kharkiv region reported the following results. First, the proposed methodological approach to determining the coefficient of ecological factor of sunflower production makes it possible to objectively assess the problems related to compliance with the existing requirements for the recovery of nutrients and the structure of cultivated areas. Second, the obtained values of the coefficient of the environmental factor of sunflower production indicate a serious situation with the environmental component in the production of this crop. Of the 503 enterprises, $72.2 \%$ had a value of this factor of not more than 0.3 . Third, the criteria for determining the ecological factor of production, which characterizes the coefficient of ecological production of sunflower, allows for a state policy against producers who either violate existing standards or, on the contrary, adhere to them.

In case of violation of environmental requirements, the state must apply economic sanctions. Otherwise, it will lead to the loss of soil fertility, the most valuable national treasure. From the authors' point of view, these sanctions could include the application of increased percentages of the normative monetary evaluation of land. On the other hand, enterprises where the value of the ecological factor of sunflower production exceeds 1 should be able to receive subsidies from the state for ecological friendly production. This approach could be extended to other cash crops. This, in turn, would force companies to adhere to technologies that maintain soilfertility. The state simply has to act so that today's generations do not leave depleted soils to future generations, but soils that provide production for many generations to come.

\section{References:}

Kondratyuk, N. V. (2013). Current trends in sunflower seed production in agricultural enterprises of Kharkiv region. Bulletin of KhNAU. Series: Economic Sciences, 3, 157-162. (in Ukrainian)

Kondratyuk, N. V. (2014). Concentration as a factor in shaping the efficiency of sunflower production. Bulletin of KhNAU. Series: Economic Sciences, 6, 243-250.

Kontseba, S. M. (2014). Ways to increase the efficiency of sunflower seed production in the region. Bulletin of KhNAU. Series: Economic Sciences, 4, 313-323.

Perebyinis, V. I. (2014). Strategic directions for improving the logistics and marketing of sunflower seeds. Bulletin of KhNAU. Series: Economic Sciences, 5, 48-54.

Runcheva, N. V., \& Britvenko, A. S. (2019). Correlation analysis of the concentration and efficiency of production and processing of sunflower in agricultural holdings of Ukraine and assessment of their impact on the development of specialized agricultural markets. Efficient economy, 5. DOI: https://doi.org/10.32702/2307-2105-2019.5.2

Runcheva, A. S. (2012). Economic efficiency of sunflower production in Ukraine. Scientific works of Poltava State Agrarian Academy. Series: Economic Sciences, 5(3), 262-267.

Pysarenko, S. V., \& Mykolenko, I. G. (2010). Economic aspects of substantiation of efficient sunflower production in Poltava region. Scientific works of Poltava State Agrarian Academy. Series: Economic Sciences, 1(1), 202-205.

Zaryshniak, A. S., \& Lisovyi, M. V. (ed.) (2008). Modern systems of fertilization of agricultural crops in crop rotations with different rotation by the main soil-climatic zones of Ukraine: recommendations. Kyiv: Agrarian Science.

On approval of standards for the optimal ratio of crops in crop rotations in different natural and agricultural regions. Resolution of the Cabinet of Ministers of Ukraine № 164 of February 11, 2010. Available at: https://zakon.rada.gov.ua/laws/show/164-2010-\%D0\%BF\#Text 